\title{
Desain Modul Berbasis Model Discovery Learning untuk Kemampuan Pemahaman Matematis Siswa
}

\author{
Ida Arimurti1*, Ena Suhena Praja², dan Fahrudin Muhtarulloh ${ }^{3}$ \\ $1^{*}, 2$ Pendidikan Matematika, Universitas Swadaya Gunung Jati \\ Jalan Pemuda Raya No.32, Sunyaragi, Kota Cirebon, Jawa Barat, Indonesia \\ 1*idaarimurti6868@gmail.com; ${ }^{2}$ suhenaena@yahoo.co.id \\ ${ }^{3}$ Matematika, UIN Sunan Gunung Djati \\ Jalan A.H. Nasution No.105, Cipadung, Kota Bandung, Jawa Barat, Indonesia \\ 3fahrudin.math@uinsgd.ac.id
}

Artikel diterima: 27-02-2019, direvisi: 26-08-2019, diterbitkan: 30-09-2019

\begin{abstract}
Abstrak
Penelitian ini bertujuan untuk mendeskripsikan learning obstacle, mendesain bahan ajar yang valid, dan mendeskripsikan learning obstacle setelah implementasi bahan ajar. Metode yang digunakan pada penelitian ini adalah metode kualitatif dan kuantitatif. Metode kualitatif untuk analisis learning obstacle dan bahan ajar, sedangkan metode kuantitatif untuk mengetahui keseragaman pendapat. Subjek dalam penelitian ini adalah 31 siswa kelas VIII C SMP Negeri 1 Plered untuk identifikasi learning obstacle awal dan 32 siswa kelas IX A SMP Negeri 1 Plered untuk identifikasi learning obstacle dan kemampuan pemahaman matematis siswa. Desain penelitian yang digunakan berupa desain didaktis (Didactical Design Research). Hasil penelitian ini menunjukan bahwa terdapat 8 learning obstacle siswa terkait materi operasi bentuk aljabar. Validasi bahan ajar modul matematika dilakukan oleh 5 validator (3 dosen FKIP Universitas Swadaya Gunung Jati dan 2 guru matematika). Berdasarkan hasil validasi tersebut dapat disimpulkan bahwa bahan ajar modul operasi bentuk aljabar berbasis kemampuan pemahaman matematis siswa dengan model discovery learning diperoleh bahan ajar siswa layak digunakan dalam proses pembelajaran, serta bahan ajar pedoman guru layak digunakan pula.

Kata Kunci: Learning obstacle, aljabar, kemampuan pemahaman matematis, desain didaktis.
\end{abstract}

\section{Designing Module Based on Discovery Learning Models for Students' Mathematical Understanding Ability}

\begin{abstract}
This study aims to describe learning obstacle students, designing instructional materials, and describing learning obstacle students after the implementation of teaching materials. The method used in this study is qualitative and quantitative methods. Qualitative methods for the analysis of obstacle learning and teaching materials, while the quantitative method to find out the uniformity of opinion. The subjects in this study were 31 students of class VIII C of SMP 1 Plered to identify the initial obstacle learning and 32 students of class IX-A of SMP 1 Plered to identify obstacle learning and students' mathematical understanding skills. The research design used is in the form of didactic design (Didactical Design Research). The results of this study indicate that there are 8 learning obstacle students related to algebraic form operating material. Validation of mathematics module teaching materials was carried out by 5 validators (3 lecturers of FKIP Swadaya Gunung Jati University and 2 mathematics teachers). Based on the results of the validation, it can be concluded that the algebraic form operating module teaching materials based on students' mathematical understanding ability with discovery learning models obtained that they are suitable for learning, and the teacher's guideline teaching material also.

Keywords: Learning obstacle, algebraic, mathematical understanding ability, Didactical Design Research.
\end{abstract}

Mosharafa: Jumal Pendidikan Matematika

Volume 8, Nomor 3, September 2019

Copyright $\odot 2019$ Mosharafa: Jurnal Pendidikan Matematika 


\section{Pendahuluan}

Matematika sebagai salah satu mata pelajaran yang berkembang dengan pesat, baik materi maupun kegunaannya sehingga dalam pembelajaran di sekolah harus memperhatikan perkembangannya, baik di masa lalu, masa sekarang maupun kemungkinan-kemungkinan untuk masa depan. Bagian-bagian konsep matematika yang paling sederhana perlu dipelajari secara baik sebagai bekal membangun konsep matematika yang lebih kompleks. Menurut Sugiyono (2015), kemampuan matematis siswa diklasifikasikan ke dalam lima kompetensi utama yaitu: Pemahaman, pemecahan masalah, komunikasi, penalaran, dan koneksi. Berdasarkan pendapat di atas, maka perlu dikembangkan pemahaman siswa dalam pembelajaran matematika untuk pengembangan siswa di masa akan datang (Muna \& Afriansyah, 2016).

Pemahaman merupakan proses, perbuatan dan cara memahami. Yang salah satu tujuan penting dalam pembelajaran adalah memberikan pengertian bahwa materi-materi yang diajarkan kepada siswa bukan hanya hafalan. Setiap siswa memiliki kemampuan yang berbeda tergantung pada ide yang dimiliki dan perbuatan hubungan antara ide yang ada dengan ide yang baru (Afriansyah, 2014). Pemahaman merupakan salah satu aspek dalam taksonomi bloom.

Kemampuan pemahaman merupakan kemampuan awal yang harus dimiliki oleh siswa dalam pembelajaran matematika. Menurut Susanto (2013), pemahaman adalah suatu proses mental terjadinya adaptasi dan transformasi ilmu pengetahuan. Sejalan dengan pendapat Hendriana dan Sumarmo (2014) mendefinisikan pemahaman matematis adalah kecakapan atau kemahiran menerapkan konsep/prinsip dalam menyelesaikan permasalahan matematika dan ilmu pengetahuan lain.

Beberapa penelitian sebelumnya telah mengkaji kemampuan pemahaman matematis siswa dikaitkan dengan: creative problem solving (Muliawati \& Sofyan, 2013); team assisted individually (Firdaus \& Afriansyah, 2016); rotating trio exchange (Nuraeni \& Afriansyah, 2016); personalized system of instruction (Priyambodo, 2016); inside-outside-circle (Nuraeni \& Luritawaty, 2017); aptitude treatment interaction (Pamungkas \& Afriansyah, 2017); teknik spotlight (Fitri, Aima, \& Muhlisin, 2017); take and give (Luritawaty, 2018); pair checks dan problem based learning (Supriatna \& Afriansyah, 2018); pembelajaran kontekstual (Brinus, Makur, \& Nendi, 2019).

Dalam pemahaman tidak hanya sekedar memahami sebuah informasi, dengan kata lain siswa dapat mengubah suatu informasi yang ada dalam pikirannya kedalam bentuk lain yang lebih berarti. Berdasarkan hasil penelitian awal yang bertujuan untuk mencari learning obstacle dan untuk mengetahui sejauh mana kemampuan pemahaman matematis siswa
Mosharafa: Jumal Pendidikan Matematika Volume 8, Nomor 3, September 2019 Copyright $\odot 2019$ Mosharafa: Jurnal Pendidikan Matematika 
yang dilakukan pada salah satu Sekolah Menengah Pertama (SMP) di Kabupaten Cirebon soal tersebut mengenai soal kemampuan pemahaman matematis pada materi operasi bentuk aljabar. Berdasarkan hasil penelitian tersebut bahwa siswa merasa masih kesulitan untuk menggunakan matematika dalam kehidupan sehari-hari. Rendahnya kemampuan pemahaman matematis siswa dibuktikan dengan hasil uji coba yang telah dilakukan oleh peneliti. Hasil uji coba dari 31 siswa disajikan dalam tabel 1 berikut.

Rata-rata siswa dilihat dari tabel 1 diperoleh sebesar 14.51 dari 8 soal yang diberikan, ini berarti kemampuan pemahaman matematis tersebut masih rendah karena kebanyakan siswa masih mempelajari materi matematika secara terpisah dan tidak mengerti bagaimana keterkaitan konsep pada materi yang telah dipelajari. Selain itu, pada proses pembelajaran di kelas umumnya siswa lebih menekankan pada proses penghapalan rumus/konsep tanpa mengetahui rumus/konsep itu terbentuk. Kesulitan-kesulitan tersebut dapat

Tabel 1.

Rekapitulasi Hasil Uji Coba

\begin{tabular}{|ccc|}
\hline No. Soal & Jumlah Nilai & Rata-Rata \\
\hline 1 & 47 & 1.51 \\
\hline 2 & 23 & 0.74 \\
\hline 3 & 52 & 1.68 \\
\hline 4 & 41 & 1.32 \\
\hline 5 & 96 & 3.10 \\
\hline 6 & 58 & 1.87 \\
\hline 7 & 49 & 1.58 \\
\hline 8 & 84 & 2.71 \\
\hline Jumlah & 450 & 14.51 \\
\hline
\end{tabular}

Mosharafa: Jumal Pendidikan Matematika

Volume 8, Nomor 3, September 2019

Copyright @ 2019 Mosharafa: Jurnal Pendidikan Matematika dikatakan sebagai hambatan belajar atau learning obstacle (Fuadiah, 2017). Menurut Brousseau, terdapat tiga faktor hambatan belajar yaitu ontogenical learning obstacle (kesiapan mental belajar), didactical learning obstacle (akibat pengajaran guru) dan epistemological learning obstacle (pemahaman atau pengetahuan siswa yang terbatas).

Learning obstacle ini dapat diperoleh melalui kajian desain didaktis. Suryadi (2013) menyatakan bahwa penelitian desain didaktis atau Didactical Design Research (DDR) pada dasarnya terdiri dari tiga tahap, yaitu: 1) Analisis situasi didaktis sebelum pembelajaran yang wujudnya berupa desain didaktis hipotesis termasuk antisipasi didaktis dan pedagogis (ADP), 2) analisis metapedadidaktik, dan 3) analisis retrosfektif yakni analisis yang mengaitkan hasil analisis situasi didaktis hipotesis dengan hasil analisis metapedadidaktik.

Dalam pembelajaran di sekolah, guru hendaknya memilih dan menggunakan strategi, pendekatan, metode, dan teknik yang banyak melibatkan siswa aktif dalam belajar, baik secara mental, fisik maupun sosial (Afriansyah, 2016). "Setiap guru yang mengajar di kelas, akan memilih strategi tertentu agar pelaksanaan pembelajaran yang dilakukannya di kelas berjalan dengan lancar dan hasilnya optimal. Oleh karenanya, penulis tertarik dengan model Discovery Learning.

Berbagai penelitian telah menerapkan model Discovery Learning pada penelitiannya dikaitkan dengan: 
pemecahan masalah matematis (Ratnawati \& Nanang, 2014; Rahmiati, Musdi, \& Fauzi, 2017; Sundayana, 2019); komunikasi matematis (Asmara \& Afriansyah, 2018); pemahaman konsep (Sapilin, Adisantoso, \& Taufik, 2019); dan pengembangan perangkat pembelajaran (Yulius, Irwan, \& Yerizon, 2017; Nengsih \& Septia, 2017; Alam \& Razak, 2018).

Discover berarti menemukan sedangkan discovery adalah penemuan. Menurut Sund (Roestiyah, 2008) discovery adalah proses mental dimana siswa mampu mengasimilasikan sesuatu konsep atau prinsip. Yang dimaksudkan dengan proses mental tersebut antara lain ialah: mengamati, mencerna, mengerti, menggolong-golongkan, membuat dugaan, menjelaskan, mengukur, membuat kesimpulan, dan sebaginya. Sejalan dengan pendapat Lestari, dan Yudhanegara (2015) menyatakan bahwa discovery learning adalah suatu metode pembelajaran yang dirancang sedemikian sehingga siswa dapat menemukan konsepkonsep dan prinsip-prinsip melalui proses mentalnya sendiri.

Yang dimaksud dengan proses mental tersebut antara lain ialah: mengamati, mencerna, mengerti, menggolonggolongkan, membuat dugaan, menjelaskan, mengukur, membuat kesimpulan, dan sebagainya. Seperti yang dijelaskan sebelumnya bahwa kesulitankesulitan atau learning obstacle siswa digolongkan menjadi tiga faktor sehingga peneliti menyimpulkan bahwa kesulitan ini ditandai oleh pemahaman siswa yang 462 kurang atau terbatas ini artinya kesulitan menurut Brousseau termasuk kedalam epistemological learning obstacle atau kesulitan itu dapat terjadi karena bahan ajar yang sulit untuk dipahami oleh siswa dalam belajar. Menyikapi hal tersebut menjadikan penulis untuk berusaha menemukan cara agar dapat membantu siswa dalam mencapai kompetensi yang diinginkan. Dengan menerapkan inovasi yang baru diharapkan mampu merubah dan memperbaiki kondisi belajar siswa untuk belajar matematika. Inovasi yang digunakan penulis dalam pembelajaran adalah bahan ajar.

Berdasarkan kesulitan yang telah ditemukan peneliti tertarik untuk membuat desain bahan ajar yang berbentuk modul dengan judul "Desain Bahan Ajar Berbasis Model Discovery Learning pada Kemampuan Pemahaman Matematis Siswa" dengan rumusan dalam penelitian ini yaitu (1) Bagaimana kesulitan-kesulitan belajar (learning obstacle) yang dialami siswa dalam mempelajari materi operasi bentuk aljabar?; (2) Bagaimana mendesain bahan ajar berbasis model Discovery Learning pada kemampuan pemahaman matematis siswa yang valid?; (3) Bagaimana kesulitankesulitan belajar (learning obstacle) setelah bahan ajar diimplementasikan?

Sedangkan tujuan penelitian ini bertujuan untuk (1) mengetahui learning obstacle terkait dengan kemampuan pemahaman matematis dengan model Discovery Learning pada materi Operasi Bentuk Aljabar, (2) mengetahui bagaimana Mosharafa: Jumal Pendidikan Matematika Volume 8, Nomor 3, September 2019 Copyright $\odot 2019$ Mosharafa: Jurnal Pendidikan Matematika 
merancang bahan ajar berbasis kemampuan pemahaman matematis siswa dengan model Discovery Learning pada materi Operasi Bentuk Aljabar yang valid, dan (3) mengetahui learning obstacle terkait dengan kemampuan pemahaman matematis dengan model Discovery Learning pada materi Operasi Bentuk Aljabar setelah implementsi bahan ajar.

\section{Metode}

Metode yang digunakan dalam penelitian ini yaitu metode kualitatif dan kuantitatif. Menurut Sugiyono (2015) Metode penelitian kualitatif adalah metode penelitian yang digunakan untuk meneliti situasi dan kondisi seseorang dimana peneliti sebagai kuncinya untuk melakukan pengambilan sampel data yang diperlukan, pengambilan ini dilakukan melalui uji instrumen, teknik pengumpulan data, analisis data dan hasilnya lebih menekankan kepada makna dari pada generalisasi Metode kualitatif digunakan untuk menganalisis bahan ajar siswa dan pedoman untuk guru dan validasi bahan ajar siswa dan pedoman untuk guru dalam kemampuan pemahaman matematis siswa. Sedangkan metode kuantitatif adalah metode penelitian yang digunakan untuk meneliti populasi atau sampel tertentu, teknik pengambilan sampel dilakukan secara umum dan untuk pengumpulan data mengunakan instrumen penelitian, analisis data tersebut bersifat statistik yaitu dengan menganalisis butir soal dan uji Q-Cochran. Tujuan uji Q-Cochran yaitu untuk mengetahui keseragaman pendapat para ahli. Desain penelitian ini berupa Didactical Design Research (DDR).

Penelitian ini dilakukan di SMP Negeri 1 Plered yaitu siswa kelas VIII C untuk identifikasi kemampuan pemahaman awal dan siswa kelas IX A untuk identifikasi learning obstacle akhir.

\section{Hasil dan Pembahasan}

\section{A. Learning Obstacle Siswa}

Learning obstacle yang dialami siswa dari hasil tes uji coba terhadap siswa kelas VIII C SMP Negeri 1 Plered. Soal yang diberikan adalah soal uraian sejumlah delapan soal yang berbasis kemampuan pemahaman matematis. Dari hasil uji coba tersebut diperoleh gambaran learning obstacle siswa dalam mengerjakan soal nomor 1 yaitu "jelaskan bagaimana menentukan hasil penjumlahan, hasil pengurangan, dan hasil perkalian pada bentuk aljabar" indikator tersebut termasuk ke dalam mendefinisikan konsep secara verbal dan tertulis. Learning obstacle yang dialami siswa dalam menjawab soal nomor 1 akan ditunjukan pada gambar 1 berikut.

Berdasarkan gambar 1 tersebut,

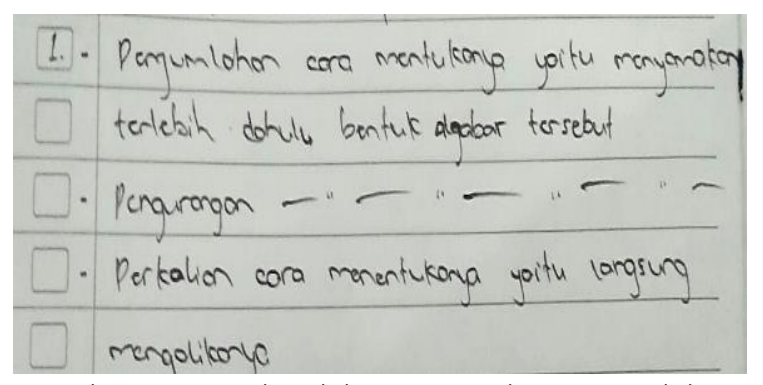

Gambar 1. Contoh Salah Satu Jawaban Siswa dalam Mengerjakan Soal Nomor 1 
diperoleh bahwa learning obstacle dalam mengerjakan soal nomor 1 dimana siswa belum mampu menjelaskan bagaimana cara menentukan hasil penjumlahan,hasil pengurangan, dan hasil perkalian pada bentuk aljabar dengan bahasanya sendiri. Dari 31 siswa yang mengerjakan soal nomor 1 hanya 4 siswa yang mampu menjawab benar dan 27 siswa lainnya menjawab salah. Distribusi kemampuan pemahaman matematis siswalainnya

Tabel 2.

Rekapitulasi Distribusi Hasil Tes Uji Coba

\begin{tabular}{|c|c|c|c|}
\hline \multirow[t]{2}{*}{ No } & \multirow{2}{*}{$\begin{array}{c}\text { Indikator Kemampuan } \\
\text { Pemahaman } \\
\text { Matematis }\end{array}$} & \multicolumn{2}{|c|}{ Persentase } \\
\hline & & Benar & Salah \\
\hline 1 & $\begin{array}{l}\text { Mendefinisikan konsep } \\
\text { secara verbal dan } \\
\text { tertulis }\end{array}$ & $13 \%$ & $87 \%$ \\
\hline 2 & $\begin{array}{l}\text { Mendefinisikan konsep } \\
\text { secara verbal dan } \\
\text { tertulis }\end{array}$ & $0 \%$ & $100 \%$ \\
\hline 3 & $\begin{array}{l}\text { Menggunakan model, } \\
\text { diagram, dan simbol- } \\
\text { simbol untuk } \\
\text { merepresentasikan } \\
\text { suatu konsep }\end{array}$ & $0 \%$ & $100 \%$ \\
\hline 4 & $\begin{array}{l}\text { Menggunakan model, } \\
\text { diagram, dan simbol- } \\
\text { simbol untuk } \\
\text { merepresentasikan } \\
\text { suatu konsep }\end{array}$ & $0 \%$ & $100 \%$ \\
\hline 5 & $\begin{array}{l}\text { Mengubah suatu } \\
\text { bentuk representasi } \\
\text { kedalam bentuk lain }\end{array}$ & $0 \%$ & $100 \%$ \\
\hline 6 & $\begin{array}{l}\text { Mengubah suatu } \\
\text { bentuk representasi } \\
\text { kedalam bentuk lain }\end{array}$ & $19 \%$ & $81 \%$ \\
\hline 7 & $\begin{array}{l}\text { Membandingkan dan } \\
\text { membedakan konsep- } \\
\text { konsep }\end{array}$ & $3 \%$ & $97 \%$ \\
\hline 8 & $\begin{array}{l}\text { Membandingkan dan } \\
\text { membedakan konsep- } \\
\text { konsep }\end{array}$ & $6 \%$ & $94 \%$ \\
\hline & Jumlah & $41 \%$ & $759 \%$ \\
\hline & Rata-rata & $5 \%$ & $95 \%$ \\
\hline
\end{tabular}

disimpulkan dalam tabel 2 berikut.

Berdasarkan tabel 2, masih rendahnya kemampuan pemahaman matematis siswa dalam mengerjakan soal uji coba pada materi operasi bentuk aljabar. Analisis kemampuan siswa terkait operasi bentuk aljabar terdapat lima tipe learning obstacle diantaranya (1) menjelaskan cara menentukan hasil penjumlahan, hasil pengurangan, dan hasil perkalian pada bentuk aljabar (2) mengaitkan model matematika pada materi operasi bentuk aljabar (3) mengubah model matematika ke dalam bentuk aljabar (4) mengaitkan bentuk aljabar dalam kehidupan seharihari (5) mengaplikasikan bentuk aljabar pada bangun datar.

\section{B. Validasi Bahan Ajar}

Setelah ditemukannya learning obstacle tersebut kemudian peneliti menyusun desain bahan ajar untuk mengurangi kesulitan-kesulitan siswa dalam materi operasi bentuk aljabar. Desain bahan ajar dalam penelitian ini berbentuk modul siswa dan pedoman guru, sebelum digunakan dalam proses pembelajaran desain bahan ajar tersebut divalidasi oleh ahli pembelajaran matematika yang bertujuan untuk mengetahui bahan ajar tersebut layak atau tidak digunakan dalam pembelajaran. Adapun hasil penilaian validasi bahan ajar siswa dan pedoman untuk guru dari masing-masing para ahli disajikan pada gambar 2 berikut.

Dari gambar 2 menjelaskan bahwa adanya perhitungan validasi bahan ajar siswa dan pedoman untuk guru menurut 
masing-masing ahli, ahli tersebut berjumlah lima validator. Hasil dari perhitungan tersebut diperoleh untuk validator 1: bahan ajar siswa diperoleh sebesar $84 \%$ dan pedoman untuk guru sebesar $85 \%$ yang artinya cukup valid. Validator 2: bahan ajar siswa 97\% dan pedoman untuk guru 93,75 yang artinya sangat valid. Validator 3: bahan ajar siswa 92\% dan pedoman untuk guru 97,50 yang artinya sangat valid. Validator 4: bahan ajar siswa diperoleh sebesar 93\% dan pedoman untuk guru sebesar 97,50\% yang artinya sangat valid. Validator 5 : bahan ajar siswa diperoleh sebesar 94\% dan pedoman untuk guru sebesar $97,50 \%$ yang artinya sangat valid.

Setelah diperoleh hasil penilian dari masing-masing validator selanjutnya dicari nilai gabungan dari keseluruhannya berikut diperoleh hasil penilaian validasi gabungan bahan ajar siswa dan pedoman untuk guru disajikan pada gambar 3 berikut.

Berdasarkan data yang telah diperoleh peneliti dapat menarik kesimpulan bahwa hasil gabungan perhitungan untuk validasi bahan ajar siswa diperoleh sebesar 92,04\% untuk bahan ajar pedoman guru diperoleh sebesar $94,25 \%$ dan ini berarti

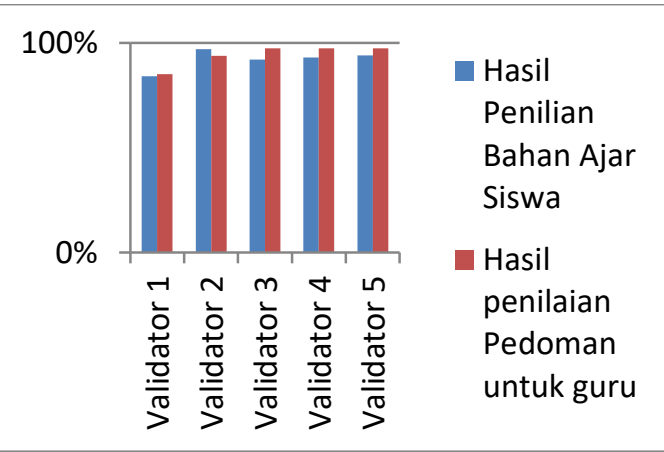

Gambar 2. Hasil Penilaian Bahan Ajar Siswa dan Pedoman untuk Guru keduanya layak digunakan dalam proses pembelajaran.

Penilaian dari setiap validator terdapat komentar dan saran oleh karena itu untuk menyeragamkan pendapat dari semua validator yaitu dilakukan uji Q-Cochran, uji ini digunakan untuk menguji perbedaan pendapat dari berbagai para ahli. Berikut diperoleh hasil uji Q-Cochran bahan ajar siswa dan pedoman guru disajikan pada gambar 4 berikut.

Berdasarkan gambar $4, \mathrm{dk}=\mathrm{k}-1=$ $5-1=4$ dengan taraf kesalahan 5\% maka harga Chi Kuadrat tabel $=9,488$. Bahan ajar siswa diperoleh harga $\mathrm{Q}$ hitung

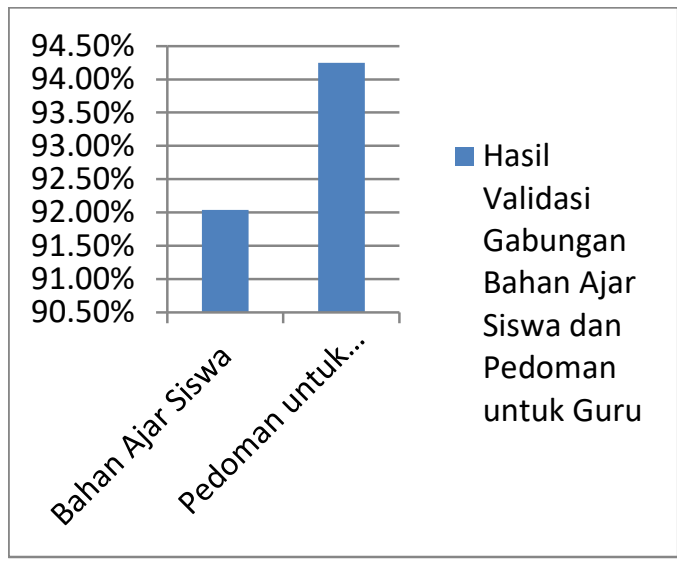

Gambar 3. Hasil Validasi Gabungan Bahan Ajar Siswa dan Pedoman untuk Guru Para Ahli

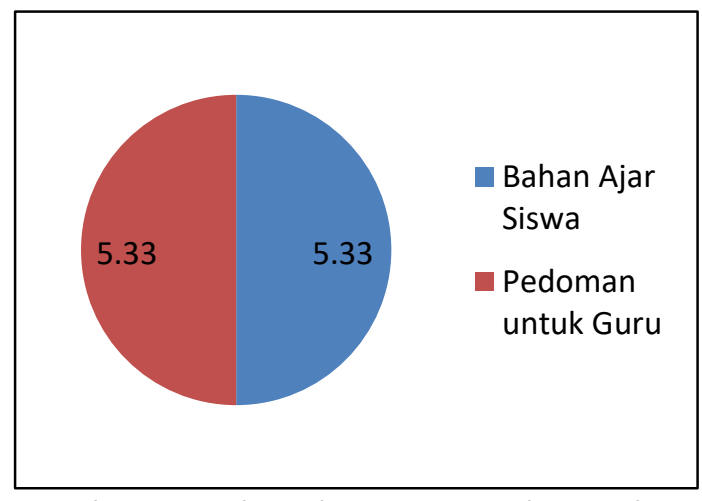

Gambar 4. Hasil Penilaian Uji Q-Cochran Bahan Ajar Siswa dan Pedoman Guru Para Ahli 
$(5,33)$, dan pedoman untuk guru diperoleh harga $Q$ hitung $(5,33)$ ternyata dari kedua penilaian tersebut lebih kecil dari Q tabel $(9,488)$ jadi $\mathrm{H}_{0}$ diterima dan $\mathrm{H}_{1}$ ditolak. Ini berarti tidak terdapat perbedaan pendapat dari para ahli yang signifikan sehingga, dapat disimpulkan bahwa kelima validator memberikan pendapat dan penilaian yang seragam terhadap bahan ajar siswa dan pedoman untuk guru yang

Tabel 3.

Rekapitulasi Distribusi Hasil Tes Uji Coba Setelah Implementasi Bahan Ajar

\begin{tabular}{|c|c|c|c|}
\hline \multirow[t]{2}{*}{ No } & \multirow{2}{*}{$\begin{array}{l}\text { Indikator } \\
\text { Kemampuan } \\
\text { Pemahaman } \\
\text { Matematis } \\
\end{array}$} & \multicolumn{2}{|c|}{ Persentase } \\
\hline & & Benar & Salah \\
\hline 1 & $\begin{array}{l}\text { Mendefinisikan } \\
\text { konsep secara verbal } \\
\text { dan tertulis }\end{array}$ & $78,12 \%$ & $21,88 \%$ \\
\hline 2 & $\begin{array}{l}\text { Mendefinisikan } \\
\text { konsep secara verbal } \\
\text { dan tertulis }\end{array}$ & $87,5 \%$ & $12,5 \%$ \\
\hline 3 & $\begin{array}{l}\text { Menggunakan } \\
\text { model, diagram, dan } \\
\text { simbol-simbol untuk } \\
\text { merepresentasikan } \\
\text { suatu konsep } \\
\end{array}$ & $68,75 \%$ & $31,25 \%$ \\
\hline 4 & $\begin{array}{l}\text { Menggunakan } \\
\text { model, diagram, dan } \\
\text { simbol-simbol untuk } \\
\text { merepresentasikan } \\
\text { suatu konsep }\end{array}$ & $62.5 \%$ & $37,5 \%$ \\
\hline 5 & $\begin{array}{l}\text { Mengubah suatu } \\
\text { bentuk representasi } \\
\text { kedalam bentuk lain }\end{array}$ & $71,86 \%$ & $28,14 \%$ \\
\hline 6 & $\begin{array}{l}\text { Mengubah suatu } \\
\text { bentuk representasi } \\
\text { kedalam bentuk lain }\end{array}$ & $93,75 \%$ & $6,25 \%$ \\
\hline 7 & $\begin{array}{l}\text { Membandingkan dan } \\
\text { membedakan } \\
\text { konsep-konsep }\end{array}$ & $75 \%$ & $25 \%$ \\
\hline 8 & $\begin{array}{l}\text { Membandingkan dan } \\
\text { membedakan } \\
\text { konsep-konsep }\end{array}$ & $53,12 \%$ & $46,88 \%$ \\
\hline & Jumlah & $590,6 \%$ & $209,4 \%$ \\
\hline & Rata-rata & $73,83 \%$ & $26,17 \%$ \\
\hline
\end{tabular}

disusun oleh peneliti.

\section{Learning Obstacle Setelah Implementasi Modul}

Setelah bahan ajar tersebut divalidasi oleh para ahli selanjutya peneliti mengimplementasikan bahan ajar tersebut dalam pembelajaran pada kelas IX A SMP Negeri 1 Plered yang bertujuan untuk mengetahui apakah learning obstacle siswa dapat diminimalisir setelah bahan ajar diimplementasikan, Untuk mengetahui data mengenai learning obstacle siswa stelah implementasi, siswa diberikan soal uji coba uraian yang berjumlah delapan soal dengan jumlah 32 siswa. Soal tersebut merupakan soal yang sama untuk mengidentifikasi learning obstacle awal. Berikut disajikan rekapitulasi distribusi hasil tes uji coba setelah bahan ajar diimplementasikan.

Berdasarkan tabel 3, dapat disimpulkan bahwa learning obstacle siswa setelah bahan ajar diimplementasikan dapat diminimalisir. Dengan perolehan rata-rata siswa yang menjawab benar sebelum menggunakan bahan ajar saat pembelajaran yaitu sebesar $5,13 \%$ dan perolehan rata-rata siswa yang menjawab benar setelah bahan ajar diimplementasikan adalah sebesar $73,83 \%$ ini berarti learning obstacle siswa dapat berkurang.

\section{Penutup}

Berdasarkan pembahasan yang telah dipaparkan, maka diperoleh simpulan sebagai berikut: 1) Learning obstacle atau 
kesulitan yang dialami oleh siswa dalam mempelajari materi operasi bentuk aljabar didapatkan dari hasil uji coba instrumen. Learning obstacle didapatkan sebelum bahan ajar siswa diimplementasikan; 2) Berdasarkan hasil validasi oleh lima validator diperoleh bahan ajar untuk siswa dan pedoman bahan ajar untuk guru berbasis kemampuan pemahaman matematis pada materi operasi bentuk aljabar dengan model Discovery Learning yang berbentuk modul layak digunakan dalam proses pembelajaran; 3) Hasil implementasi bahan ajar siswa diperoleh learning obstacle khususnya hambatan epistomologis yang dialami siswa setelah bahan ajar siswa (modul) diimplementasikan dapat diminimalisir.

Guru dalam mengimplementasikan bahan ajar operasi bentuk aljabar berbasis kemampuan pemahaman dengan model Discovery Learning ini harus disesuaikan dengan karakteristik siswa. Diharapkan pula dapat memberikan materi prasyarat yaitu bilangan bulat yang berkaitan dengan materi pokok yaitu operasi bentuk aljabar sebelum menjelaskan materi pokok yang hendak dipelajari, sehingga akan mengurangi kesulitan yang dialami oleh siswa dalam menyelesaikan masalah yang berkaitan dengan materi tersebut. Serta guru diharapkan mampu menerapkan model Discovery Learning dalam proses pembelajaran menggunakan bahan ajar.

\section{Daftar Pustaka}

Afriansyah, E. A. (2014). What Students' Thinking about Contextual Problems

\section{Mosharafa: Jurnal Pendidikan Matematika}

Volume 8, Nomor 3, September 2019

Copyright @ 2019 Mosharafa: Jurnal Pendidikan Matematika is. International Seminar on Innovation in Mathematics and Mathematics Education. Departement of Mathematics Education Faculty of Mathematics and Natural Science Yogyakarta State University. 279-288. Afriansyah, E. A. (2016). The Use of Realistic Approach to Enhance Students' Mathematical Problem Solving Skills. International Conference on Elementary and Teacher Education ICETE.

Alam, Z. I., \& Razak, F. (2018). Pengembangan Lembar Kegiatan Siswa Berbasis Metode Penemuan Terbimbing untuk Pembelajaran Matematika pada Siswa Kelas XII SMA Negeri 1 Segeri. Mosharafa: Jurnal Pendidikan Matematika, 7(1). 1-12. DOI: https://doi.org/10.31980/moshar afa.v7i1.336

Asmara, R., \& Afriansyah, E. A. (2018). Perbedaan Peningkatan Kemampuan Komunikasi Matematis Siswa antara Model Eliciting Activities dan Discovery Learning. Suska Journal of Mathematics Education, 4(2), 78-87.

Brinus, K. S. W., Makur, A. P., \& Nendi, F. (2019). Pengaruh Model Pembelajaran Kontekstual terhadap Pemahaman Konsep Matematika Siswa SMP. Mosharafa: Jurnal Pendidikan Matematika, 8(2). 261272.

DOI: https://doi.org/10.31980/moshar afa.v8i2.439

Firdaus, D. A., \& Afriansyah, E. A. (2016). Pembelajaran Kooperatif Tipe Team 
Assisted Individually untuk Meningkatkan Kemampuan Pemahaman Matematis Siswa Sekolah Menengah Pertama. Jurnal Pendidikan Matematika RAFA, 2(1), 104-122.

Fitri, D. Y., Aima, Z., \& Muhlisin, M. (2017). Pengaruh Penerapan Teknik Spotlight terhadap Pemahaman Konsep Matematis Sisiwa Kelas VIII SMPN 1 Batang Anai Padang Pariaman. Mosharafa: Jurnal Pendidikan Matematika, 6(2). 247-254. DOI: https://doi.org/10.31980/moshar afa.v6i2.312

Fuadiah, N. F. (2017). Hypothetical Learning Trajectory pada Pembelajaran Bilangan Negatif Berdasarkan Teori Situasi Didaktis di Sekolah Menengah. Mosharafa: Jurnal Pendidikan Matematika, 6(1). 13-24. DOI: https://doi.org/10.31980/moshar afa.v6i1.290

Hendriana, H., \& Sumarmo, U. (2014). Penilaian Pembelajaran Matematika. Bandung: PT Refika Aditama.

Lestari, E., \& Yudhanegara, M. (2015). Penelitian Pendidikan Matematika (Panduan Praktis Menyusun Skripsi, Tesis, dan Karya IImiah dengan Pendekatan Kuantitatif, Kualitatif, dan Kombinasi disertai dengan Model Pembelajaran dan Kemampuan Matematis). Bandung: Refika Aditama. Muliawati, T., \& Sofyan, D. (2013). Perbandingan Kemampuan Pemahaman Matematis antara Siswa yang Mendapatkan Strategi Creative Problem Solving (CPS) dengan Model
Pembelajaran Konvensional. Mosharafa: Jurnal Pendidikan Matematika, 2(1). 55-64.

Luritawaty, I. P. (2018). Pembelajaran Take and Give dalam Upaya Mengembangkan Kemampuan Pemahaman Konsep Matematis. Mosharafa: Jurnal Pendidikan Matematika, 7(2). 179-188. DOI: https://doi.org/10.31980/moshar afa.v7i2.27

Muna, D. N., \& Afriansyah, E. A. (2016). Peningkatan Kemampuan Pemahaman Matematis Siswa melalui Pembelajaran Kooperatif Teknik Kancing Gemerencing dan Number Head Together. Mosharafa: Jurnal Pendidikan Matematika, 5(2). 169176.

DOI: https://doi.org/10.31980/moshar afa.v5i2.272

Nengsih, S., \& Septia, T. (2017). Pengembangan Lembar Kegiatan Siswa Berbasis Penemuan Terbimbing pada Materi Peluang untuk Siswa Kelas XI IPA SMA Adabiah 2 Padang. Mosharafa: Jurnal Pendidikan Matematika, 6(2). 299-304. DOI: https://doi.org/10.31980/moshar afa.v6i2.318

Nuraeni, R., \& Luritawaty, I. P. (2017). Perbandingan Kemampuan Pemahaman Matematis Siswa Antara yang Menggunakan Pembelajaran Inside-Outside-Circle dengan Konvensional. Mosharafa: Jurnal Pendidikan Matematika, 6(3). 441450.

Mosharafa: Jumal Pendidikan Matematika Volume 8, Nomor 3, September 2019 Copyright $\odot 2019$ Mosharafa: Jurnal Pendidikan Matematika 
DOI: https://doi.org/10.31980/moshar afa.v6i3.332

Nuraeni, Y., \& Afriansyah, E. A. (2016).

Peningkatan

Kemampuan

Pemahaman Matematis Siswa Melalui

Pembelajaran Kooperatif Tipe

Rotating Trio Exchange. Jurnal Inovasi

Pendidikan Dasar, 1(2), 85-94.

Pamungkas, Y., \& Afriansyah, E. A. (2017).

Aptitude Treatment Interaction

terhadap Kemampuan Pemahaman

Matematis Siswa. Jurnal Pendidikan

Matematika RAFA, 3(1), 122-130.

Prastowo, A. (2015). Panduan Kreatif

Membuat Bahan Ajar Inovatif.

Jogjakarta: DIVA Press.

Priyambodo, S. (2016). Peningkatan

Kemampuan Pemahaman Konsep

Matematis Siswa dengan Metode

Pembelajaran Personalized System of

Instruction. Mosharafa: Jurnal

Pendidikan Matematika, 5(1). 10-17.

Rahmiati, R., Musdi, E., \& Fauzi, A. (2017).

Pengembangan

Perangkat

Pembelajaran Matematika Berbasis

Discovery Learning untuk

Meningkatkan Kemampuan

Pemecahan Masalah Siswa Kelas VIII

SMP. Mosharafa: Jurnal Pendidikan

Matematika, 6(2). 267-272.

DOI: https://doi.org/10.31980/moshar

afa.v6i2.314

Ratnawati, R., \& Nanang, N. (2014).

Perbedaan Kemampuan Pemecahan

Masalah Matematik antara yang

Menggunakan Pembelajaran

Kontekstual dengan Problem Based

Learning di Mts Al-Mu'amalah Garut.

\section{Mosharafa: Jurnal Pendidikan Matematika}

Volume 8, Nomor 3, September 2019

Copyright $\odot 2019$ Mosharafa: Jurnal Pendidikan Matematika
Mosharafa: Jurnal Pendidikan

Matematika, 3(1). 43-54.

Roestiyah, N. K. (2008). Strategi Belajar Mengajar. Jakarta: Rineka Cipta.

Sapilin, S., Adisantoso, P., \& Taufik, M. (2019). Peningkatan Pemahaman Konsep Peserta Didik dengan Model Discovery Learning pada Materi Fungsi Invers. Mosharafa: Jurnal Pendidikan Matematika, 8(2). 285296.

DOI: https://doi.org/10.31980/moshar afa.v8i2.476

Sugiyono. (2015). Statistik Nonparametris untuk Penelitian. Bandung: Alfabeta.

Sundayana, R. (2019). Perbandingan Desain Pembelajaran ASSURE dan PPSI untuk Meningkatkan Kemampuan Pemecahan Masalah Matematis dan Kemandirian Belajar. Mosharafa: Jurnal Pendidikan Matematika, 8(1). 143-154.

DOI: https://doi.org/10.31980/moshar afa.v8i1.420

Supriatna, R., \& Afriansyah, E. A. (2018). Kemampuan Pemahaman Matematis Peserta Didik melalui Cooperative Learning Tipe Pair Checks VS Problem Based Learning. JPMI (Jurnal Pendidikan Matematika Indonesia), 3(1), 1-6.

Suryadi, D. (2013). Didactical Desain Research (DDR) dalam Pengembangan Pembelajaran Matematika. Bandung: FPMIPA UPI.

Susanto, A. (2013). Teori Belajar dan Pembelajaran di Sekolah Dasar. Jakarta: Kencana Prenada Media Grup.

Yulius, B., Irwan, I., \& Yerizon, Y. (2017). Pengembangan Perangkat 
Pembelajaran Matematika Berbasis

Model Pembelajaran Penemuan

Dengan Masalah Open Ended untuk

Peserta Didik SMA Kelas X Semester 2.

Mosharafa: Jurnal Pendidikan

Matematika, 6(2). 279-286.

DOI: https://doi.org/10.31980/moshar

afa.v6i2.316

\section{Riwayat Hidup PenUlis}

Ida Arimurti, S.Pd., MOS.

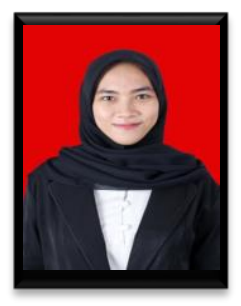

Lahir di Cirebon, 27 Juli 1996.

Studi S1 pada Fakultas

Keguruan dan Ilmu

Pendidikan Program Studi

Pendidikan Matematika di

Universitas Swadaya Gunung

Jati Cirebon, lulus tahun

2018.

Dr. H. Ena Suhena, Drs., M.Pd.

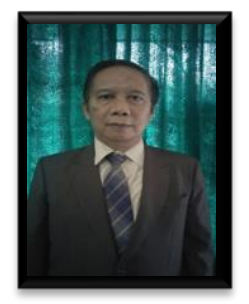

Lahir di Majalengka, 31 Mei

1957. Studi S1 pada

Pendidikan Matematika di

Universitas Pendidikan

Indonesia, lulus tahun 1982.

Pada tahun 2001 lulus dari

program Magister (S2) dari

Program Studi Pendidikan

Matematika Universitas Pendidkan Indonesia. Pendidikan terakhir lulus program doctor (S3) pada tahun 2009 dari Program Studi Pendidikan Matematika Universitas Pendidikan Indonesia.

\section{Fahrudin Muhtarulloh, M.Sc.}

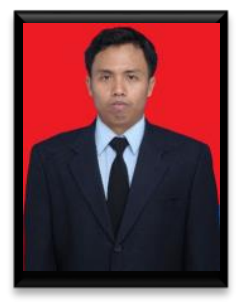

Lahir di Majalengka, 9 Januari 1986. Studi S1 pada FPMIPA Program Studi Matematika di Universitas Pendidikan Indonesia, lulus tahun 2008. Pendidikan terakhir lulus pada tahun 2013 dari Universitas Gadjah Mada

Program Studi S-2 Matematika.Lahir di M 